\title{
The Other Hand: High Bandwidth Development Policy
}

\author{
Ricardo Hausmann \\ CID Working Paper No. 179 \\ September 2008
}

(C) Copyright 2008 Ricardo Hausmann and the President and Fellows of Harvard College

\section{Working Papers Center for International Development at Harvard University}




\title{
The Other Hand: High Bandwidth Development Policy
}

\section{Ricardo Hausmann}

September 2008

\begin{abstract}
Much of development policy has been based on the search for a short to do list that would get countries moving. In this paper I argue that economic activity requires a large and highly interacting set of public policies and services, which constitute inputs into the production process. This is reflected in the presence, in all countries, of hundreds of thousands of pages of legislation and hundreds of public agencies. Finding out what is the right mix of the public inputs, and more importantly, what is a valuable change from the current provision is as complex as determining what is the right mix of private provision of goods. In the latter case, economists agree that this process cannot be achieved through central planning and that the invisible hand of the market is the right approach, because it allows decisions to be made in a more decentralized manner with more information. I argue that a similar solution is required to deal with the complexity of the public policy mix.
\end{abstract}

Keywords: structural transformation, coordination failures

JEL Codes: O10, O20, H10 


\title{
The Other Hand: High Bandwidth Development Policy
}

\author{
Ricardo Hausmann \\ Harvard Kennedy School \\ \& \\ Center for International Development at Harvard University
}

June 2008

\begin{abstract}
Much of development policy has been based on the search for a short to do list that would get countries moving. In this paper I argue that economic activity requires a large and highly interacting set of public policies and services, which constitute inputs into the production process. This is reflected in the presence, in all countries, of hundreds of thousands of pages of legislation and hundreds of public agencies. Finding out what is the right mix of the public inputs, and more importantly, what is a valuable change from the current provision is as complex as determining what is the right mix of private provision of goods. In the latter case, economists agree that this process cannot be achieved through central planning and that the invisible hand of the market is the right approach, because it allows decisions to be made in a more decentralized manner with more information. I argue that a similar solution is required to deal with the complexity of the public policy mix.
\end{abstract}

Paper prepared for the Brookings Development Conference. May 29-30 2008. The ideas I present in this paper evolved gradually over the past few years. I am particularly indebted to Dani Rodrik and Chuck Sabel with whom I have been thinking about policy and to César Hidalgo and Bailey Klinger, with whom I have been studying the high dimensionality of the development process. I thank Nava Ashraf and Ross Levine and participants at the Brookings seminar for their comments. The errors are mine. 
Little else is requisite to carry a state to the highest degree of opulence from the lowest barbarism but peace, easy taxes, and a tolerable administration of justice: all the rest being brought about by the natural course of things.

Adam Smith, Lecture in $1755^{1}$

The uniform, constant and uninterrupted effort of every man to better his condition, the principle from which public and national, as well as private opulence is originally derived, is frequently powerful enough to maintain the natural progress of things toward improvement, in spite both of the extravagance of government, and of the greatest errors of administration. Like the unknown principle of animal life, it frequently restores health and vigour to the constitution, in spite, not only of the disease, but of the absurd prescriptions of the doctor.

The Wealth of Nations (1776), Book II Chapter III

The intensive study of the problem of economic development has had one discouraging result: it has produced an ever lengthening list of factors and conditions, of obstacles and prerequisites.

Albert O. Hirschman, The Strategy of Economic Development (1958), p.1

\section{The dimensionality of the policy problem}

Ever since Adam Smith, economists have been in search of a simple solution to the question of the causes of the wealth of nations and the challenge of development, but the search has so far proved elusive. The idea that poor-country governments need to do little to catch up has been a constant refrain in policy circles ${ }^{2}$. For example, the Washington Consensus (Williamson, 1990) was based on 10 relatively straightforward policies that, if followed, promised economic success.

\footnotetext{
${ }^{1}$ Quoted by Dugald Stewart.

${ }^{2}$ For example, as expressed by Roll and Tallbott (2001) “Once a developing country government establishes the rules to a fair game and ensures their enforcement, it would be well advised to stand back and enjoy the self-generating growth". But as discussed in Hausmann, Pritchett and Rodrik (2006), most growth accelerations are not "self-generating" but peter out after 8 years leading to limited convergence of incomes.
} 
By contrast, most governments in the world have literally hundreds of thousands of pages of legislation managed by hundreds of public bureaucracies. Just the European common law - the Acquis Communautaire - has over fifty thousand pages of legislation. Table 1 shows the 35 chapters in which the Acquis was divided in its $6^{\text {th }}$ enlargement. It is easy to see that the need for each chapter is quite compelling. But the accumulation of them all implies that it is hard to imagine how a minimal Smithian state could ever work in a modern society.

Table 1. Chapters of the Acquis Communataire, $6^{\text {th }}$ enlargement.

\begin{tabular}{|c|c|}
\hline - $\quad$ Free movement of goods & - $\quad$ Social policy and employment \\
\hline - $\quad$ Freedom of movement for workers & - $\quad$ Enterprise and industrial policy \\
\hline $\begin{array}{l}\text { - } \begin{array}{l}\text { Right of establishment and freedom to } \\
\text { provide services }\end{array} \\
\end{array}$ & - $\quad$ Trans-European networks \\
\hline - Free movement of capital & $\begin{array}{ll}- & \text { Regional policy and coordination of } \\
\text { structural instruments }\end{array}$ \\
\hline - $\quad$ Public procurement & - $\quad$ Judiciary and fundamental rights \\
\hline - Company law & - Justice, freedom and security \\
\hline - $\quad$ Intellectual property law & - $\quad$ Science and research \\
\hline - $\quad$ Competition policy & - $\quad$ Education and culture \\
\hline - Financial services & - Environment \\
\hline - Information society and media & - $\quad$ Consumer and health protection \\
\hline - $\quad$ Agriculture and rural development & - $\quad$ Customs union \\
\hline $\begin{array}{l}\text { - Food safety, veterinary and phytosanitary } \\
\text { policy }\end{array}$ & - $\quad$ External relations \\
\hline - $\quad$ Fisheries & - $\quad$ Foreign, security and defence policy \\
\hline - $\quad$ Transport policy & - $\quad$ Financial control \\
\hline - $\quad$ Energy & - $\quad$ Financial and budgetary provisions \\
\hline - $\quad$ Taxation & - Institutions \\
\hline - $\quad$ Economic and monetary policy & - $\quad$ Other issues \\
\hline - $\quad$ Statistics & \\
\hline
\end{tabular}

The search for a simple, low dimensional solution to the question of policy is highly influenced by the amazingly simple solution Adam Smith found to the problem of planning the production and allocation of goods in a society and his explanation for the causes of the wealth of nations. A free market allows production to self-organize by linking many independent decision-makers - the producers of eggs, milk, cheese, butter, olives, olive oil, wheat, bread, coffee and sugar, salt, pepper and their inputs, (cows, poultry, tractors, seeds, animal feed, gasoline, credit, electricity, transportation, retailing, refrigeration, accounting, advertising, etc.) - so that we can decide to have a cheese omelet, toast and coffee for breakfast. Nobody has to plan these things centrally. 
Economists since Adam Smith have been in awe of the miraculous capacity of the market to solve coordination problems that would be dauntingly complex if they were to be made through the purposeful planning of any collection of agencies. The wisdom of the answer took a very long time to sink in. While on the one hand Walras, Arrow and Debreu were working out the conditions under which such an approach would work, socialist economists tried to work out an alternative system based on central planning. This was the central point of debate between the socialists and the liberals from the 1930s to the $1960 s^{3}$. In practice, centrally planned regimes, in spite of perpetual reforms to make them more efficient, were characterized by endemic shortages (Kornai, 1992).

The failure of central planning was clearly foreseen by Friedrich von Hayek (1975, [1935]) who pointed out that the informational requirements for the central planner to do a decent job were just not feasible. The bandwidth of the required informational content was just too large and too decentralized and no incentive mechanism existed for the central planner to get the requisite information. Decentralization was required to reveal the information that only individuals had about what they wanted and hence were willing to pay for, how much it would actually cost to make, and what would be the best ways of producing it. The price system in a free market contained that information but the central planner did not.

The central planner could try to use global market prices, but this has two major limits. First, it only covers tradable products. Second, socialism would require that capitalist societies be around to create the international markets from which a successful socialist regime could get the requisite prices for its planning process ${ }^{4}$.

\footnotetext{
${ }^{3}$ Oskar Lange suggested that central planning could work if a Walrasian auctioneer changed prices in response to excess supply or excess demand. Kornai and Lipták (1971) showed that if instead the central planner decided the quantities of goods he wanted made and firms set the price, then a socialist system could achieve a decent general equilibrium very similar to that of a market economy.

${ }^{4}$ As the old socialist joke had it, one day Joseph Stalin announced that the socialist revolution would be victorious everywhere in the world except in New Zealand. So his advisors asked him: why the exception? To which Stalin answered: because we need somewhere to get our prices from. [from Kornai (2006)].
} 
Thirdly, and most importantly, the secret of capitalism is not that it is able to clear the market for a set of existing products. Instead, it is the unending decentralized search for new products and processes ${ }^{5}$. What products are feasible is a rapidly changing set. What products are preferred out of that set is a question that can only be answered by offering them and finding out ex post. This Schumpeterian (Schumpeter, [1911] 1934) quest is implicit in the invisible hand. As Kornai recounts, what impressed him the most during his first trips to the West in the 1960s was not the ability of capitalism to balance supply and demand better than socialism, which had been the focus of his research up to then ${ }^{6}$, but instead the shear variety and innovation in products in the West that were nowhere to be seen even in the relatively liberal Hungarian version of socialism.

So the invisible hand is a complex information processing mechanism cum incentive structure that while having short-run equilibrating properties that tend to balance supply and demand also explores a very large and evolving set of new possibilities. Just flip through a thick mail-order catalog or remind yourself what life was like before credit cards, personal computers, cell phones, the internet or laser read code bars in supermarket cash registers to remember how things have changed over the span of very few years. By contrast, consider the alternative under central planning: in March 2008, the Cuban government decided to allow "the unrestricted sale of computers and DVD and video players... Air conditioners would be available next year and toasters in 2010 after a delay caused by limited power supplies” (Financial Times, March 14, 2008, p.2).

The central point of this paper is that the same complexity that characterizes the development of private products and inputs also affects public policy. For the same reasons, a central planning solution to the public policy conundrum generates distortions that are similar in flavor to those caused by central planning in the market context. First, central planning tends to lead to shortages in the provision of policy solutions. Second, the informational requirements of the policymaking process in terms of the evolving set

\footnotetext{
5 The typical supermarket carries about 45,000 different types of products or stock keeping units (SKUs). The total number of SKUs in a modern economy is probably in the billions (Beinhoecker, 2006).

${ }^{6}$ His research had up to then been centered on the question of why socialism tended to create shortages of goods in economies characterized by full employment (Kornai, 2006).
} 
of obstacles and opportunities that require policy action is decentralized in society and needs to be revealed through some mechanism that addresses the incentive problems faced by participants. This cannot be simply substituted by importing international best practice (the dual of international prices) ${ }^{7}$. Third, the system requires a Schumpeterian capacity to constantly evolve new solutions: we now have property rights on the electromagnetic spectrum, cap and trade regimes for contaminants, the ability to sell music over the internet, e-commerce, and the certification of clinical trials.

Much of the policy debates around development have been centered on discovering the few important elements that required prioritized attention. Instead, this paper finds merit in focusing on the bandwidth that the policymaking process can cope with and the information revelation it can achieve on each theme.

\section{Does the invisible hand require a complex institutional setting?}

Does the invisible hand imply the irrelevance of policy ("the absurd prescriptions of the doctor”), as the Smith quotes suggest? Can the system work with the provision of “peace, easy taxes and a tolerable administration of justice”? If so, why do we observe hundreds of thousands of pages of legislation and hundreds of government agencies? Why this complexity?

Economists are split on this issue. On the one hand, a frequent economist's answer is that government intervention is the consequence of counter-productive rent-seeking (Stigler (1971), Krueger (1974)). The state has the capacity to coerce and this can be used by industry for its own gain. Regulations are created either by bureaucrats and politicians in order to extract rents or by incumbents so as to keep competitors out ${ }^{8}$. The world would be better off with a minimal state. Because of the incentive problems faced by collective

\footnotetext{
${ }^{7}$ This, by the way, suffers from the same critique as the joke quoted by Kornai: if everybody imports the best practice, who would they be copying? Do we also need to have a New Zealand that the rest can copy?

${ }^{8}$ For example, Djankov et al (2002) state that the evidence on the regulation of entry of firms "is inconsistent with public interest theories of regulation, but supports the public choice view that entry regulation benefits politicians and bureaucrats.”
} 
action, participants in the policy process favor the provision of private, not public goods (Olson $(1965,1982)$ ) and this ultimately limits growth.

But it is easy to see that consumers need assurance that food, medicine, air travel, banks and work are safe so that they can confidently transact in markets. Just remember what happened to the meat market when a few animals came down with "mad cow" disease. But creating regulation that assures consumers in a world of rapidly changing products and technologies is a highly complex process. An alternative view of the origins of economic institutions owes much to Williamson $(1975,1985)$, where the attempt to lower transaction costs is a key motivation. I find the narrative provided by Greif (2005) as particularly enlightening. In this view, as economic agents interact, they face specific transaction costs of different sorts. This leads them to organize private-order institutions that attempt to find solutions to the transaction costs that are faced. Some solutions are self-enforcing (Dixit, 2004), or rely on ad hoc outside enforcement. But many are just not self-enforcing. This creates incentives to involve the government, whose comparative advantage is precisely its enforcement capacity. However, the government may use (and abuse) its position to extract rents. This limits the attractiveness to the private sector of involving the government in a solution unless there are coercion-constraining institutions that limit the rapacity of the government, such as elections and the separation of powers.

Hence, policy complexity may arise for quite constructive reasons. Take the simple case of the real estate market ${ }^{9}$. In this market, assets already exist. They just need to change hands. Buyers need to find out what properties are on sale and what their specific characteristics are. Sellers need to transmit that information to buyers. So a market of real estate brokers develops to achieve these goals. Now, not all the characteristics of a house or apartment are easily visible to a naked untrained eye. There may be hidden defects in the house that the owner knows about and has an interest in concealing from the buyer. This creates an asymmetric information problem that is addressed through a market for inspectors. These inspectors are licensed by some entity to assure their customers that they know what they are doing. They are hired by the buyer to report on the conditions of

\footnotetext{
${ }^{9}$ This example first appeared in Hausmann and Rodrik (2006).
} 
the property and its abidance by the building code. Then it is important to know whether the seller has full rights to the property and that there are no liens or other impediments on his right to sell. Otherwise a buyer may pay, only to find out that others also have a legal claim on the property. A system of property registries that can track financial and tax claims on individual properties is needed. But it may be inefficient for the buyer to bear the risk of any surprises or defects in the ownership rights, so a market for title insurance is helpful. Also, public authorities may have imposed some easements on that property to secure some public interest, or there may be municipal plans to change the conditions around the property that may significantly affect its value. In addition, the buyer needs finance to purchase the home, for which he needs a market for loans. To address willingness to pay and other incentive and information problems in this market it is convenient to be able to pledge the house as collateral to a lender with a set of rights in case the buyer does not abide by the mortgage contract. A legal system needs to define these rights and enforce them. The lender may also require insurance against fire, storms, etc, lest the collateral blow up in smoke. Hence, a home insurance market is needed. Furthermore, the sale takes time because after an initial agreement has been reached, the inspection needs to take place and the buyer needs to secure financing, title insurance and home insurance. Many unexpected events may happen during that process and it is important to clarify how to deal with them. It may be helpful to require a deposit, a down payment or establish an escrow account to deal with some of these contractual problems, for which a real estate lawyer is needed. The real estate lawyer in turn needs to be accredited (by some body) to carry these functions. If the property is an apartment in a condominium, it is important that the rights and obligations of the apartment owner vis-avis the rest of the condominium be clearly established and understood.

The previous paragraph shows how complex a simple transaction such as the sale of an existing property actually is and how it is related to a network of markets and institutional arrangements that must co-exist. We described not just a market for homes, but also a market for brokers, mortgage loans, inspections, title and home insurance and lawyers. It involves registries, municipal rules, accreditation of the different specialized agents, rules on creditor rights and condominiums, etc. And this is just part of what is required for 
trade in existing homes. Imagine now the added complexity involved in urban development and construction.

Note also that the role the public sector plays is deeply related to the specificity of the transaction costs involved in this activity. All the roles described here are legitimate and sector specific. They are not driven per se by rent seeking and cannot be solved through horizontal mechanisms that apply across all sectors. Interventions are sector-specific because the transaction costs they are designed to address are also specific. The government acts not because it is “picking winners”. It is simply providing the necessary complementary inputs to one of a myriad of activities in the economy.

This description of the interaction between markets and elements of policy suggest that they are high dimensional and deeply interacting. The way the market for insurance is organized affects the way the market for mortgages works, etc. This means that in general the way each of the hundreds of thousands of pages of legislation that an average country has is written can affect the impact of the other pages of legislation. These interactions make the system orders of magnitude more complex than just the length of the list. It includes that plus all the interaction terms. This inevitably makes interventions very context specific.

Recognition of the complexity of the requisite policy framework for a successful economy is slowly creeping into development economics, but it is doing so in a manner that tries to elude the complexity by hiding it. I will argue instead that the right approach is to embrace complexity and deal with it in the same way Smith dealt with the problem of the cheese omelet, toast and coffee referred above. Complexity in the policy space will require thinking of the policy process as something that looks more like the "invisible hand" rather than central planning. We will return to this point in the last section of this paper. But before, I will discuss the creeping entry of complexity into the economic analysis of developing countries and the ways in which the world of development practice has dealt with it. 


\section{Smith's policy simplicity: "We are not in Kansas any more"}

If the prerequisites of development were low dimensional they could be benchmarked with few indicators. Take for example Larry Summers’s (2003) often cited quote:

"I would suggest that the rate at which countries grow is substantially determined by three things: their ability to integrate with the global economy through trade and investment; their capacity to maintain sustainable government finances and sound money; and their ability to put in place an institutional environment in which contracts can be enforced and property rights can be established. I would challenge anyone to identify a country that has done all three of these things and has not grown at a substantial rate. And I would challenge anyone to identify a country that for any significant period has been held back either by excessive trade links with the global economy, overly sound public finances, or property rights and contracts that are excessively enforced.”

According to this view, growth requires openness, sound money and property rights. A simple, low dimensional interpretation of this quote would argue that if this is the case, an index of the level of restrictions to trade and investment, the rate of inflation, the public debt ratio and an index of property rights and contract enforcement should be enough to characterize what matters for the ability of countries to grow ${ }^{10}$. But as the Global Competitiveness Report 2007-2008 of the World Economic Forum (p.3) states: “Our experience in studying competitiveness has made it clear that the determinants of competitiveness are many and complex.”

Consider the Global Competitiveness Index produced by the World Economic Forum. It measures 12 areas or pillars that are seen as key for a country’s competitiveness.

\footnotetext{
${ }^{10}$ A higher dimension interpretation of this quote would instead put the accent on the word "ability" or "capacity" which Summers uses three times: the ability to integrate with the global economy, the capacity to maintain sound money, the ability to put in place an institutional environment... These abilities may be very high dimensional and may not be captured just by the level of tariffs or the inflation rate. They could be very complex and context specific. See Rodrik (2007) for a discussion of this point.
} 
Table 2. The 12 pillars of competitiveness

Global Competitiveness Report 2007-2008

\begin{tabular}{|c|c|}
\hline - institutions & - labor market efficiency \\
\hline - infrastructure & - financial market sophistication \\
\hline - macroeconomic stability & - technological readiness \\
\hline - health and primary education & - market size \\
\hline - higher education and training & - business sophistication \\
\hline - goods market efficiency & - innovation \\
\hline
\end{tabular}

Moreover, each one of these areas is not just a single dimension but a composite of many others. For example, the institutions pillar is composed of the following 18 elements:

Table 3. Components of the Institutions pillar of the Global Competitiveness Index

\begin{tabular}{|l|l|l|}
\hline$\bullet$ intellectual property & $\bullet$ diversion of public funds \\
\hline$\bullet \quad$ protection of property rights & $\bullet \begin{array}{l}\text { strength of auditing and reporting } \\
\text { standards }\end{array}$ \\
\hline$\bullet \quad \begin{array}{l}\text { transparency of government } \\
\text { policymaking }\end{array}$ & $\bullet$ business costs of terrorism \\
\hline$\bullet \quad$ judicial independence & $\bullet \quad$ efficacy of corporate boards \\
\hline$\bullet \quad$ efficiency of legal framework & $\bullet \quad$ ethical behavior of firms \\
\hline$\bullet \quad \begin{array}{l}\text { favoritism in decisions of } \\
\text { government officials }\end{array}$ & $\bullet \begin{array}{l}\text { business costs of crime and } \\
\text { violence }\end{array}$ \\
\hline$\bullet \quad$ presence of organized crime & $\bullet \quad \begin{array}{l}\text { wastefulness of government } \\
\text { spending }\end{array}$ \\
\hline$\bullet \quad \begin{array}{l}\text { protection of minority } \\
\text { shareholders' interests }\end{array}$ & $\bullet \quad$ reliability of police services \\
\hline$\bullet \quad$ public trust of politicians & $\bullet \quad$ burden of government regulation. \\
\hline
\end{tabular}

So the Global Competitiveness Report has over 100 indicators that underpin its 12 pillars. But many of these indicators are systemic properties, not fundamental areas of policy. Take for example public trust in politicians, transparency of government policymaking or wastefulness in government spending. These are outcomes of a system integrated by many agencies and rules and perceived by many constituencies. We do not really know what causes most of these outcomes and therefore we have very little idea of which actionable variables should be adjusted to improve performance in these areas. Most likely, the requisite policy actions constitute an even longer list, along with its complicated sets of interactions. 
A similar situation affects the attempt of the World Bank to measure the quality of the investment climate through its Doing Business Report. The index is composed of 10 different elements:

Table 4. The 10 Components of the World Bank's Doing Business Index

\begin{tabular}{|l|l|}
\hline$\bullet$ starting a business & $\bullet$ protecting investors \\
\hline$\bullet$ dealing with licenses & $\bullet$ paying taxes \\
\hline$\bullet$ employing workers & $\bullet$ trading across borders \\
\hline$\bullet$ registering property & $\bullet$ enforcing contracts \\
\hline$\bullet$ getting credit & $\bullet$ closing a business \\
\hline
\end{tabular}

Each one of these components is characterized by many additional dimensions. For example, employing workers is in itself determined by 6 other indexes which measure the difficulty in hiring and in firing, rigidities in the work day and in employment, as well as non-wage and firing costs. Each one of these is in itself an aggregation of other sub-subindexes. In total, there are over 100 variables in this index. What to do with this high dimensional space?

\section{Attempts at collapsing the high dimensional space}

So we have gone from the simple policy world that Adam Smith had envisioned to a Global Competitiveness Report or a Doing Business Report, where each has over 100 rather complex dimensions. In reality, the dimensionality of the problem is orders of magnitude larger, but this fact is suppressed by projecting the complexity into a lower dimensional space - at the limit, to a single dimensional ordinal space of country rankings - through a set of assumptions.

One mechanism to reduce dimensionality is to put many different real phenomena under the same label. The reduction thus obtained is more linguistic than practical. The concept "burden of regulation” in the Global Competitiveness Index is implicitly used to describe food safety standards, environmental controls, phitosanitary permits, capital adequacy requirements, zoning rules, tax administration, labor market regulations, etc. Property 
rights are given a single name but they include the right of a person to an apartment in a condominium, of a company to the mineral resources underground, of a bank to a loan and of a musician to a song. These rights are defined in different legal texts and enforced by different agencies. It is as if we would classify the men in the world into the categories of John, George, Joseph, Peter, Daniel, William, etc. But besides the name, the different individuals assigned to each group share few other things in common. As a consequence, when the issue becomes the improvement of performance in a certain area, dimensionality come back in full force as each individual in the group requires a different treatment.

A second strategy to reduce dimensionality is to suppress sector specificity. For example, the measure of dealing with licenses in the Doing Business Report is benchmarked by considering only the licenses required to set up a warehouse. The measure of enforcing contracts is benchmarked by considering only the problem of collecting a loan granted to a hotel. These are interesting examples to look at in order to compare countries along some common issue, but the problem of dealing with the licenses of a warehouse are very different from those of registering a drug, getting a concession for a TV channel, obtaining rights over natural resources, or getting phytosanitary permits. The presumption is that if a country is bad at licensing a warehouse, it must be hopeless at dealing with any other of these more specific areas. But the real quality of the investment climate is affected by many sector-specific dimensions that are not fixed unless they are addressed at the right level of specificity.

Moreover, improving the licensing process is more than just cutting red tape. There are important trade-offs that licenses are trying to address, such as consumer safety, environmental protection, urban conditions, network effects, labor safety, intellectual property, etc. Each licensing process is distinct. It is often based on a different law and run by a different agency. Consider for example the many policy issues - e.g. environmental issues, right of way, network effects, urban spillovers, natural monopolies, tax issues, labor and consumer safety standards, etc. - that arise in each of the following sectors: agriculture, power, telecoms, mining, ports or the pharmaceutical industry. The 
real problem for societies is how to organize the provision of an adequate investment climate in each of these areas and this is unfortunately a very high dimensional problem. Making the licensing of a warehouse very expeditious will not solve any of this. Thus, the high dimensional nature of the problem does not disappear. ${ }^{11}$

Another mechanism to reduce dimensionality is the assumption of linearity and separability ${ }^{12}$ in the construction of indexes. Linearity makes all the dimensions of the index into substitutes. The number of licenses is averaged with the number of days it takes to get them and the formal fees that have to be paid. According to the index, if you under-perform on one, you can make it up by over-performing on the others. In real life, these elements are more likely to be complements than substitutes: one license can stop all investments in a sector; it is not impacted by performance along other dimensions.

Separability means that the effect of improving things in one dimension is independent of the state of the other dimensions. The implicit assumption is that the mapping between each dimension and performance is monotonically increasing in all dimensions, all the time. This is highly unlikely to be the case. Second-best interactions are bound to be very important. The benefit from having fewer licenses has to be traded off against the benefit of assuring consumers that products are safe and banks are sound. The benefit of having low license fees must be traded off against the cost of having licensing offices that are cash strapped because, in the absence of adequate fees, they depend on a weak central government budget. Low labor taxes in the US go with little public provision of health services leaving more of the burden of health insurance on corporate balance sheets while increasing the risk of labor mobility for workers.

\footnotetext{
${ }^{11}$ For example, in a critical assessment of the Doing Business Index, The World Bank's own Independent Evaluation Group (2008) states that "the indicators have been highly effective in drawing attention to the burdens of business regulation, but cannot by themselves capture other key dimensions of an country's business climate, the benefits of regulation, or key related aspects of development effectiveness....Since regulations generate social benefits as well as private costs, what is good for an individual firm is not necessarily good for the economy or society as a whole. Therefore, policy implications are not always clear-cut, and the right level and type of regulation is a matter of policy choice in each country.” It concludes that "the Bank Group, by prominently recognizing DB's highly ranked countries, may be inadvertently signaling that it values reduced regulatory burdens more than other development goals.”

${ }^{12}$ Rodriguez (2007) studies the validity of the assumption of linearity and separability in the context of Barro-style growth regressions and finds that the data rejects it.
} 
If in real life things were linear and separable then we should observe that good countries choose good policies and bad countries choose lousier ones along the dimensions described by the index. However, the average cell in the correlation matrix of the Doing Business index is just 0.18 and this is in part because of correlations of more than 0.9 between some measures that are almost identical by construction such as export and import delays or the indirect cost of labor and labor taxes. The median coefficient in the correlation matrix is barely $0.16^{13}$. The best performers are clearly not going to a corner in each of the chosen dimensions. They are optimizing along some complicated internal solution and different countries find very different configurations.

Another way in which economic theory often collapses the high dimensionality of the policy space is by assuming that government action can be conceived of as a set of taxes and subsidies, as in Pigou. The idea is that market distortions create a wedge between private and public returns. So the role of policy is to create the Pigovian taxes or subsidies to bring these two returns into line. This approach may work for a very limited set of interventions, a good example being the cap and trade approach to environmental problems such as acid rain. However, in most public policy issues, what is required is the delivery by the public sector of a concrete action whether it be a specific regulation, infrastructure, etc., not a tax or a subsidy. The point is that compensating the private sector financially for the absence of a road or an appropriate solution to a transactions cost is inferior to solving the problem. But the set of interventions that achieve this is much larger than the simple provision of money, making the policy action space more high dimensional.

I conclude from this analysis that the policy space has very high dimensionality. The recent attempts at capturing what matters highlight the role of an ever increasing number of dimensions which are deeply interacting, highly sector specific and look more like performance measures or output indicators of the institutional apparatus rather than

\footnotetext{
${ }^{13}$ In order to take into account the fact that some correlations are expected to be positive and others negative, we take the absolute value of the estimated correlations to calculate these numbers.
} 
individual policy inputs. The attempt to collapse all these dimensions into simple competitiveness or investment climate rankings does not achieve a simplification of the policy response as each policy area can only be addressed at the right level of specificity. Moreover, the policy space is under constant revision and updating. Just as with the case of products, it will be very hard for a central planner to keep all these considerations in mind when charting a course of action. Just as with the case of central planning, it will be very hard for countries where a central planning approach dominates the policy process to avoid the policy equivalent of shortages.

\section{Complexity in production}

Just like Schumpeter argued about capitalism in general, development and sustained economic growth require the constant introduction of new products. As Lucas put it: "A growth miracle sustained for a period of decades [...] must involve the continual introduction of new goods, not merely continual learning on a fixed set of goods." ${ }^{14}$

But as argued in Hausmann and Rodrik (2006), this process is rife with market failures. In general, there are three classes of problems that may be involved: coordination failures, information spillovers and labor training externalities. Coordination failures occur when markets are incomplete so that the return to one investment depends on whether some other investment is also made: building a hotel near a beautiful beach may be profitable if somebody builds an airport. The opposite may also be the case. However, there may not be a way for the market to coordinate both investments ${ }^{15}$.

Another source of market failure is information spillovers. In Hausmann and Rodrik (2003) we stressed the spillovers in self-discovery, which we defined as the process of

\footnotetext{
${ }^{14}$ Idem pp. 86.

${ }^{15}$ A typical solution is for the government to provide a guarantee to both investors. If done well, this will be costless for the government ex post as the investments will be profitable when they both take place. If the guarantee is not credible, then the government can just build the airport and the hotels will follow.
} 
finding out the cost structure of an economy for the production of new goods. ${ }^{16}$ The first mover will find out whether something is profitable or not; if it is, she will be copied by other entrants. But if she fails, she bears the whole loss. Because of this, the private returns from engaging in this type of innovation are lower than the social benefits, and the market incentives for self-discovery are inefficiently low. The typical policy implication is to provide a subsidy in order to bring the private returns in line with the social returns.

Labor training is another source of spillovers. A firm that trains its labor force provides a potential benefit to other firms that may poach its workers. This dampens the incentives to provide the optimal amount of training for fear of losing the investment. Clearly, labor mobility may not entail a social loss, as the worker can deploy his skills elsewhere, but the company cannot appropriate these benefits while incurring the training cost. The problem is inadequate investment in labor training; the solution is to subsidize training.

It is clear that coordination failures and spillovers are more acute for new activities than for already established ones. In the first place, coordination is impeded by the proverbial chicken and egg problem: new activities are hard to develop unless their suppliers are present, but why would the suppliers exist if they have nobody to sell to. Secondly, by definition, new activities must incur self-discovery costs. And finally, new activities cannot find workers with the relevant experience, since the activity in question has not been in existence and hence has not been hiring and training workers for it.

So, how would structural change ever take place? One way forward is the development of new activities that can use the factors and capabilities that an economy has already developed for other purposes. Hausmann and Klinger (2006) use this idea to show that product discoveries tend to favor "nearby" goods, as measured by the probability that these goods are simultaneously exported in other countries. The product space is very irregular with some goods having many nearby products and others being quite isolated.

\footnotetext{
${ }^{16}$ Structural transformation is not really about inventing new products. It is about identifying which of the products that exist in the world a particular could country profitably produce. Hence, it is not a discovery of a product, but of a national capability: hence the term.
} 
Countries differ markedly in the availability of nearby goods to move to and this affects their capacity to introduce new products, upgrade their product mix and grow ${ }^{17}$.

In this sense, a different way of describing the development process is as a co-evolution of products and capabilities. Products require capabilities but the accumulation of capabilities is something that is done in the expectation that someone will demand them. A country does not develop a cold-storage logistic system unless there is a market for it, but there will be no market unless products require it. Countries move to nearby goods because these goods share similar capabilities as the ones already in place. Development is a sequence of stepping stones that justify the accumulation of an increasing number of ever more complex capabilities ${ }^{18}$.

Co-evolution implies that there is great potential for coordination failures, as it is hard to synchronize the development of a capability with the demand for it. Moreover, because capabilities are many and co-evolve locally, finding out how to do things in a given context involves self-discovery costs (Hausmann and Rodrik, 2003) ${ }^{19}$ that entail information externalities.

\footnotetext{
${ }^{17}$ Hidalgo et al (2007) use network science to graph the product space and show that the shape of the product space may explain the lack of global income convergence. The ability of countries to diffuse through the product space requires that they be able "jump" distances that are statistically infrequent in the data. Hausmann and Klinger (2007) show that countries better positioned in the product space, in terms of the proximity to other products, tend to upgrade their exports faster.

${ }^{18}$ This is very much in the spirit of Hirschman's (1958) backward and forward linkages. However, he placed the emphasis on what could be interpreted as input-output relationships. The emphasis here is on the similarity of the requisite inputs.

${ }^{19}$ Acemoglu, Antras and Helpman (2005) have a model in which there are strong complementarities of inputs and limited contractability. Countries with better contractual environments avoid ex post renegotiations and are thus better able to solve the coordination problems and can thus produce goods that require more inputs. This would explain the division of labor across countries as a function of their contractual environment. It is an empirical question whether the requisite coordination of capabilities and products has been effectively addressed through legal enforcement of contracts or whether the world has relied on other forms of coordination. An alternative model would make the liquidity of input markets the mechanism that assures investors against opportunistic ex post behavior. Liquidity in new input markets is naturally low and hence exacerbates hold-up problems.
} 


\section{What role for policy in a high dimensional world?}

If this is the description of the development process, what is the role for policy? How should a government decide which of the hundreds of thousands of pages of legislation to revise or which of the hundreds of agencies to reform? How should it assess the impact of any reform in any area of legislation on the performance of other areas of activity and other second-best interactions? How should it balance the costs and benefits of different changes? How should it decide between the fight against foot and mouth disease, the building of new rural roads, the certification of dentists and of real estate brokers or the compliance with the prohibition against child labor and environmental degradation?

How can actual governments cope with the high bandwidth of the requisite information and decision-making needs? Stated this way, this problem seems as hopeless as that of making an omelet with toast and coffee that we discussed in the introduction to this paper. The solution to the latter was Adam Smith's invisible hand. Central planning could not work. However, much of the thinking on policy, by disregarding the high dimensional nature of the problem, has tended to look for central planning solutions. Can we call Adam Smith to the rescue again?

The invisible hand works because information about social wants and possibilities is highly decentralized in society, so decisions have to be delegated to where the information exists: i.e. the suppliers and demanders of products and services. Similarly, the information about productive possibilities and obstacles is widely disseminated in society as is the capacity to see how one policy idea, often designed for one purpose, may have unintended consequences in other sectors. Therefore a more decentralized approach may actually work also for the provision of public policies.

However, the policy problem is different from the market problem because markets can use three elements that the policy process often lacks. First, prices give information about relative costs and willingness to pay. Second, the profit motive provides the incentive to respond to prices. Thirdly, the capital market takes care of the resource mobilization to areas that are expected to show good profit opportunities. The market is not expected to 
get everything right instantaneously and without waste. It is expected to figure things out over a reasonable period of time as imbalances show up and force agents to change their plans.

In principle, the provision of public inputs lacks all three of these dimensions. Article 32 of Law X does not have a price which is reflective of the costs and benefits it provides. Even if it did, it is not clear why the political process would respond to that price as it is not in the business of maximizing profits. Finally, there is no capital market that moves resources to where the promise of return is highest.

How could the policy process mimic a similar "invisible hand" approach to the problem? To see how this can be done we need a more detailed account of the interaction between policy and production. Production in a market economy requires three types of inputs: market tradable inputs, market non-tradable inputs and public inputs. Market tradable inputs can be imported, so firms need not exist in the given economic area. However, even here rules about trading across borders, requirements of product registration, copyrights, safety standards, logistics, other transaction costs, etc. come into consideration and these are provided by governments. By contrast, non-tradable market inputs must exist in situ if production is to take place. Here coordination failures and hold-up problems can make things much more complicated. Facing these transaction problems, agents would have the incentives described by Greif to form private-order entities and to involve the government in solutions, as discussed above. The success of this process will most likely depend on the costs of private association, affected by freeriding, trust and social capital inter alia, and the political institutions that limit the rapacity of the governments and facilitates its involvement in solutions.

The rules, norms, infrastructure and other public actions that emerge from this process become inputs into the production process affecting the efficiency with which it operates and, for some products, it determines whether they are at all feasible. Let us call them public inputs. So, the production function involves not just private inputs that are provided by markets but also public inputs that come out of a different process. These 
public inputs are strong complements of private inputs in the sense that the more you have of one, the more you demand of the other. This also means that investors in a particular field are bound to benefit from a greater provision of the requisite public inputs. Their willingness to pay for an improvement in the provision of the public inputs is not independent from the social return to that input. This creates incentives to participate in the policymaking process. Note that this does not need to involve unproductive rent-seeking. In a competitive world, the initial gains from an improved provision of public inputs to those already in the industry will be dissipated through competition and will benefit society at large. However, without at least some temporary benefits to petitioners, there would be no incentive to participate in the policymaking process.

The public inputs, just like the private inputs, are very high dimensional, as we have argued. However, these public inputs - e.g. Article 32 of law X - typically do not have a price so there is no decentralized system that delivers information about what is demanded, so it is very hard for governments to know what changes in norms or infrastructure would deliver the biggest bang. Moreover, even if the government had the information it would still face an incentive problem: the government is not supposed to be a profit-motivated entity, so it is not clear why it would react to price information. Finally, even if the government had the information and the incentive to provide a certain public input it is not clear how it could mobilize the resources since each public entity does not have ready access to the capital market.

\section{How does the world deal with high dimensionality? The US example}

However, somehow the world has been able to cope with this very high dimensional problem. How does it do it? Unfortunately, this is not a question that development economics has addressed in any significant way for a large sample of countries. We do know a little about how things take place in the US, but it is likely to be a very unique case. Nevertheless, let us look into it. 
As we know, there are 435 members of the House of Representatives and 100 senators. Contrary to the practice in many other countries, these elected officials are quite independent and frequently do not vote according to party lines. They can initiate legislation (something that is restricted to the Executive in many systems) and often can attach their names to pieces of legislation creating incentives for political entrepreneurship. In addition, as opposed to a parliamentary system, there is no guarantee that the Executive will have a majority in Congress so it becomes that much more important for the private sector to lobby Congress and not just the Executive.

According to the Center for Responsive Politics ${ }^{20}$, there are over 20,000 registered lobbyists that spent 2.8 billion dollars in 2007, double the amount spent in $1999^{21}$. What are these lobbyists about? The standard economist story is that they are about pure rentseeking (Krueger, 1974). In our framework, lobbyists play a much more productive role. They provide information to their members regarding the legislation that may benefit them and the legislative actions that they may be harmful to their interests and want to stop. They also influence the policymakers with information, analysis and campaign contributions. They operate not unlike market makers in finance.

For example, the stated mission of Good Government, a lobby group is:

To effectively impact the development of legislation and regulation important to the mortgage lending industry, working for laws that protect consumers and keep mortgage capital available to them on fair and affordable terms, in ways consistent with responsible corporate citizenship and Good Government ${ }^{22}$.

The group also has a description of what a good lobbyist does or should do which includes the following elements ${ }^{23}$ :

\footnotetext{
${ }^{20}$ See http://www.opensecrets.org/lobby/index.php

${ }^{21}$ Interestingly for our example above, the National Association of Realtors is the $11^{\text {th }}$ largest spender in lobby activities. See also Grossman and Helpman (2001), especially Chapter 1.

${ }^{22}$ See http://www.oomc.com/GoodGovt/index.shtml

${ }^{23}$ See http://www.oomc.com/GoodGovt/Civics/whatalobdoes.shtml
} 
- "Convinces politicians to vote on legislation by demonstrating that doing so is in the politicians' interest.

- Meets with legislators and provides information they would not otherwise have received.

- A good lobbyist educates legislators with support documentation (charts, graphs, polls, reports).

- Sits down with legislators and helps them draft legislation”

Hence, these lobbyists describe their role in terms of information and incentives. Grossman and Helpman (1999) provide a theory of lobbying based on the fact that policymakers need to adopt policies that are preferred by their voters but they also need to finance their campaigns. So, they will respond to lobbyists depending on the costs in terms of deviating from their voter's preferences and the benefit in terms of electoral funding.

Note that there are many more lobbyists than legislators so that groups on opposite sides of an issue are normally present. This makes the system adversarial in nature, just as the judicial system. The idea is that by having each side put its best arguments on the table the system reveals much more information than would be the case if this was a process open only to experts that are informed by “best practices”.

So, in some sense, the US system has generated a social process whereby information is revealed and incentives are formed for policymakers to be responsive to that information. The decentralization of the legislative agenda and of committee work facilitates an open architecture approach to the process. There are many channels of communication between the private sector and government and there are many policy processes operating in parallel. 
Clearly, this process must be far from optimal, in the sense of what could be achieved by an omniscient and benevolent social planner. The same can be said of the market vis a vis an omniscient central planner. But the point is that omniscience is not for mortals.

The US approach to policymaking is bound to generate significant distortions. For example, as argued by Mancur Olson’s (1965) seminal work, free-riding must be a factor that affects activities differentially. Concentrated interests or those where the capacity to cooperate is enhanced for other reasons are bound to be over-represented. In addition, in the US system, congressmen have to fund their own re-election every 2 years which makes their sensitivity to contributions quite high while the capacity of the public to follow the many fine points of policy more limited.

\section{Is it only about the rents or are rents part of the solution?}

Since economists have tended to describe the lobbying process as a pure rent-seeking game they have provided evidence of rents in support of this claim (e.g. Stigler, 1971). Now, the fact that rents are present does not mean that this is what the process is about. Our alternative description of the process would emphasize the complementarity between public inputs and private production and the information and incentives constraints that lobbying is a response to. Given the varied participation constraints that the different players face - especially free-riding on the part of the public - it makes sense for participants to expect some rents from the process. This does not mean that the process can be described as a pure rent-seeking game. People lobby to prohibit abortion and stem cell research, to curb the emission of greenhouse gasses, to create the legal infrastructure to sell music on the internet and protect copyrights, to curb acid rain, to save the whales, etc. Looking this as a simple rent-seeking game is like recounting Hamlet without the Prince.

In addition, the tension between enacting policies that are good for voters vs. policies that are good for contributors may not be well balanced. Moreover, productivity enhancing and rent-seeking motivations may co-exist with a greater presence of the latter. It is easy 
to come up with anecdotes of the latter. I am not aware of any study that has looked at the relative presence of either. Productivity enhancing measures are bound to have larger constituencies in their favor or fewer opponents as they create value that can then be distributed among stakeholders. So if the political process is fairly open, they would tend to be favored. Pure rent-seeking is bound to survive only in less transparent environments as most other participants would oppose such interventions since they do not stand to gain from it. But rents are needed to justify participating in the process and avoid freeriding. It is not clear what the benchmark for an appropriate balance between productivity enhancement and rents would be in the absence of an omniscient and benevolent social planner.

\section{The policy-making process in developing countries}

The point is that we barely understand how the system that matches the demand for and the supply of public inputs actually works in the US, and we are even more ignorant of how it works in most developing countries ${ }^{24}$. In some countries, parliaments play a small role in policymaking, essentially rubberstamping the initiatives of the Executive. Even when parliaments do play a role, decisions are often taken by political parties rather than individual members of parliament. Campaigns are often not financed by individual candidates but by the party. The lobbying game must shift accordingly. In some countries the relationship between the political elite and the needs of the business sector is quite dysfunctional with rampant distrust as the dominant symptom. In others there is a sense of shared interests. In countries with a highly concentrated private sector, the coordination may involve few players. For example, the Korean policymaking framework under President Park Chung-hee was based on a deal with the chaebols where they would be responsible in creating export jobs in exchange for a supportive public policy. A relatively independent bureaucracy and foreign competition kept the system fairly honest. The nature of this game can be crucial in determining how market failures of different

\footnotetext{
${ }^{24}$ One recent important effort in understanding the policy-making process in a developing country context is Stein et al (2006). The study looks at political institutions and the institutional setting of the different actors to assess aggregate performance in terms of stability, adaptability, coordination and coherence, and efficiency of policies in general. Unfortunately, it does not deal with the supply and demand for high dimensional public policies.
} 
types are addressed, how the provision of public inputs is improved and how animal spirits are affected as investors understand how the future provision of public inputs will be decided.

We have very little evidence of the potential importance of the expected provision of public inputs in explaining growth, but there are some papers that are particularly suggestive. For example, Rodrik and Subramanian (2004) try to explain the growth acceleration in India by looking at a set of policy reforms and their dates. They find that growth accelerated about a decade before the major liberalizing reforms that are often credited with growth, such as trade reform. They suggest that the cause of the growth acceleration was "an attitudinal shift by the government in the early 1980s" which turned in favor of the established business interests (as opposed to potential new entrants, say). This attitudinal shift was expressed in many small decisions but no major reforms. The established interests responded vigorously suggesting that they had been constrained by an inadequate provision of public inputs that could be improved with small changes. If the existing businesses can expect to get their issues resolved their animal spirits would respond quickly and productivity could rise very dramatically, as it did.

The alignment of incentives between investors and policymakers often take forms that are hard to present in polite society. Pritchett (2007) argues that what matters is not the policy actions that a government takes but the expected mapping between future states of the world and the policy actions they would trigger. Private sector behavior today will be responsive to how agents expect that mapping to be in the future. For example, in Indonesia the government could be trusted to provide the right public inputs if the Suharto clan was adequately represented in the ownership structure of the firm but when Suharto's health started to fail and his sons got into a political quagmire the mechanism broke down and animal spirits flew out the window.

Consider by contrast the traditional modus operandi of an IMF program or a World Bank policy loan. Typically, conditionality is more or less secretly negotiated with minimal social input. Officials from the Bretton Woods institutions base their views on 
international best practices with little knowledge of the local specificities that would naturally emerge from a more democratic process. The priorities for reform come from the fashions of the day in the development community: trade liberalization, financial reform, privatization, conditional cash transfers, etc. The solutions are seen as relatively obvious and derived from first principles and the policy problem is often defined as the lack of "political will” or "reform appetite”. Note how uninvolved the rest of society is in identifying either policy priorities or alternative solutions.

\section{Randomized trials and benchmarking clubs in a high dimensional world}

Another method that looses its appeal in a world of high dimensionality is the randomized trial approach. A typical program, whether a conditional cash transfer, a micro-finance program or a health intervention can easily have 15 relevant dimensions. Assume that each dimension can only take 2 values. Then the possible combinations are $2^{15}$ or 32,768 possible combinations. But randomized trials can only distinguish between a control group and 1 to 3 treatment groups. So, many of the design or contextual features are kept constant while just 1 or 3 are being varied. This means that the search over the design space is quite limited, while the external validity of these experiments is reduced by the fact that many of the design or contextual elements are bound to change from place to place. So, for the majority of the design elements, policy makers must make choices on many of the design criteria in the absence of the support from randomized trials, which will necessarily play a secondary role in practice.

High dimensionality is more amenable to an evolutionary approach. Since the search space is so large, finding the optimum is just too difficult. So the point is to organize many searches and have a selection mechanism. In biology, the searches occur mostly at random, but if the selection mechanism is effective, the system will be constantly picking those variations that improve performance. Humans should be able to search more efficiently, but they still need an effective selection mechanism. 
One approach that facilitates this process and is used effectively in the private sector is benchmarking, a practice that was started in the auto industry but has spread to many other areas. Units are given operational flexibility, but their performance is meticulously measured and compared. The feedback loop created by repeated comparative measures is meant to facilitate the decentralized open-ended search for improvements. A repeated game of standardized tests and school autonomy is a rather different approach to educational improvement compared to randomized trials that try to find the impact of class size, teaching materials, de-worming, micro-nutrients, toilets or incentives for teacher attendance on school performance. Clearly, the impact of any of these interventions is bound to be highly context-specific: class size is bound to matter little if the teacher does not attend school and micro-nutrients are likely to be ineffective where nutrition is adequate. Decentralized experimentation and benchmarking of outcomes is likely to be a more effective and dynamic way of making progress.

In some sense, indexes such as the Global Competitiveness Index and the Doing Business Index represent an attempt to use the benchmarking process in policymaking. In principle, each country does things their own way and tries to make progress and their performance is measured and compared as in a benchmarking club. Other countries provide information of what outcomes are feasible and this may prove informative to assess each country's own performance. Defined in this way, indexes may add value as a feedback loop that informs the search process by pointing out what outcomes are achievable, without pretending to know how they could be improved in any particular context.

But to play this role, it is important that the index be actually informative of relative performance in the relevant areas. Instead, the indexes are often a mixture of policy inputs and performance measures, complicating their interpretation. For example, the Doing Business Index considers the time it actually takes on average to get a permit - a clear measure of performance - with the number of permits and their cost, which are policy variables. To play their role in the feedback loop, only performance measures should be included and it should be up to the decentralized decision-makers to figure out 
if the process would be more efficient with fewer complex licenses or with more simple ones. Also, calculating averages of averages of indexes does not provide a clear metric of anybody’s performance. Finding the right measure of performance is often more important than going for a plethora of poor measures in the expectation that the error terms of each bad measure is orthogonal to the true measure so that they tend to cancel out.

\section{Setting priorities vs. increasing the bandwidth}

One important issue is the extent to which the solution to the high dimensionality of the policy space lies in the setting of well-defined priorities so as to focus on what is really important to the detriment of other secondary goals or problems. This approach begs the question about who is setting such priorities and with what information set of wants and means this is done. The alternative approach is to increase the ability of the policy process to deal with more issues, i.e. to be able to operate at a higher bandwidth. This requires a multiplication of the channels through which priorities are expressed and policies are produced and the enrichment of the informational environment in which this process takes place.

Consider the democratic policymaking process as described by Lindblom (1968, p.109):

"Because policy makers learn through trial and error, we should not ask that today’s policies be consistent with yesterday’s. Because policy makers learn through trial and error about goals and means, we should not ask that today's policies not waver or alter in their objectives; we should hope instead that they do. Because in a pluralist, complex society, social goals are not a tightly knit harmonious structure, because we value openness in goal structure, and because we keep the social peace by permitting conflicting interests to pursue conflicting goals, we do not even want to reject such apparent inconsistencies as - to take a common example - subsidizing some farmers to restrict output, and others to expand it.” 
In short, as stated in Rodrik (2000) "participatory and decentralized political systems are the most effective ones we have for processing and aggregating local knowledge. We can think of democracy as a meta-institution for building good institutions.”

\section{Policy designs for higher bandwidth}

Increasing the bandwidth of policymaking requires a process to search the space of opportunities and obstacles. Here, as with the market vs. central planning, the problem is that information is highly dispersed in society so that information revelation becomes a central aspect of the policy process. In work with Dani Rodrik and Chuck Sabel ${ }^{25}$ we proposed an open architecture approach to economic policymaking. The idea is to presume the government's need for information about the space of possibilities and obstacles and to create the mechanisms for the private sector to have incentives to provide the information and for the government to have the capacity and desire to respond effectively.

First, an open architecture approach gives the initiative for action to many selforganizing bodies in society ${ }^{26}$. These bodies exist because they share interests in a set of public or club goods. By contrast, the attempt to have the government structure the conversation by parsing society into predetermined groups that must reach agreement will not necessarily reveal information about the missing public goods but instead will focus on whatever shared interest constitutes a common denominator, which often is a subsidy or a tax holiday rather than a more specific and productive intervention.

Secondly, if a public or club good is particularly productive the private sector should in principle be willing to co-finance. Therefore, willingness to co-pay may be a good screening device. Third, it is important that the relationship between the private and the public sector be seen as legitimate by the rest of society - and not a social program for the already rich. Therefore, principles of transparency must be present. Transparency will

\footnotetext{
${ }^{25}$ Hausmann and Rodrik (2006) and Hausmann, Rodrik and Sabel (2007)

${ }^{26}$ Romer (1993) proposes self-organizing industry investment boards to allocate R\&D expenditures.
} 
limit the type of requests that the private sector will be willing to make and will discipline the public response. Fourth, it is important that the government evaluate its actions on the grounds that they increase productivity, not just profitability. The latter can be achieved by transferring income from the rest of society (e.g. by buying inputs cheaper or selling output at a higher price), but unless there is an externality, this does not provide a rationale for action. By contrast, productivity increases the total amount of resources that a society can generate. Finally, it is important that solutions be designed with a universalist criteria not as an ad hoc remedy for a particular plaintiff. The idea is that the dialogue process should generate positive spillovers to other activities, not just the ones that ask for treatment.

Mechanisms of intervention should consider the fact that existing activities are likely to be over-represented relative to activities that could exist but do not because the right public inputs and other capabilities are not present. Thinking about mechanisms that can make more distant searches is important. In Hausmann, Rodrik and Sabel (2007) we argue that institutions such as development banks and industrial zones, can play a significant role in the search for these outer confines of the feasible product space and can facilitate the provision of the requisite public inputs.

\section{Embracing complexity: reinterpreting Adam Smith}

To sum up, little is gained from disregarding the high dimensional nature of the development process and its requisite public inputs. Instead of focusing on a low number of potential silver bullets, an effective development strategy should focus instead on the mechanisms that allow for a greater capacity to process information and ideas, i.e. to increase bandwidth. The alternatives are either to embrace complexity and deal with it or hide from it. Embracing it implies working not only at the level of the many individual policy actions that may be required but more importantly at the meta-level of the structures whereby problems are identified and addressed. This is what will ultimately allow societies to deal with the complexity they face. 
Maybe Adam Smith could be reinterpreted a bit. As he said: “The uniform, constant and uninterrupted effort of every man to better his condition... is frequently powerful enough to maintain the natural progress of things toward improvement”. However, part of the effort to better his condition is exerted by man in the process of participating in the collective search for public policies that can seize opportunities and overcome obstacles. Letting that invisible hand operate to improve policies may be the appropriate way to deal with the high dimensionality of the real world. 


\section{References}

Acemoglu, Daron, Pol Antras and Elhanan Helpman (2005) "Contracts and the Division of Labor” MIT Department of Economics WP 05-14.

Banerjee, Abhijit and Esther Duflo (2004) "Growth Theory Through the Lens of Development Economics”, MIT Economics Working Paper No. 05-01

Beinhoecker, E. (2006) The Origin of Wealth, Cambridge: Harvard Business Press.

Dixit, Avinash (2004) Lawlessness and Economics: Alternative Modes of Governance, Princeton University Press.

Djankov, Simeon, Rafael La Porta, Florencio Lopez de Silanes and Andrei Schleifer (2002) "The Regulation of Entry”, Quarterly Journal of Economics, Vol. CXVII, Issue 1, (February), pp. 1-37.

Greif, Avner (2005), "Commitment, Coercion, and Markets: The Nature and Dynamics of Institutions Supporting Exchange”, Handbook of New Institutional Economics, C. Ménard and M. Shirley (eds.), Springer, 727-786.

Hausmann, Ricardo and Bailey Klinger (2006) "Structural Transformation and the Patterns of Comparative Advantage in the Product Space”, Center for International Development, WP No.128, August.

Hausmann, Ricardo and Bailey Klinger (2007) "The Product Space and the Evolution of Comparative Advantage”, Center for International Development, WP No. 146, April.

Hausmann, Ricardo, Lant Pritchett and Dani Rodrik (2005) “Growth Accelerations”, Journal of Economic Growth, 10, 303-329, 2005.

Hausmann, Ricardo and Dani Rodrik (2003) "Economic Development as SelfDiscovery”, Journal of Development Economics, Elsevier, vol. 72(2), pages 603-633, December.

Hausmann, Ricardo, Jason Hwang and Dani Rodrik (2007) Journal of Economic Growth 12.1 (March 2007): 1-25.

Hausmann, Ricardo and Dani Rodrik (2006) "Doomed to Choose: Industrial Policy as Predicament”, mimeo Harvard University

Hausmann, Ricardo, Dani Rodrik and Charles Sable (2007) "Reconfiguring Industrial Policy: A Framework with an Application to South Africa, mimeo: Harvard University. 
Hayek, Friederich A. (1975) [1935] Collectivist Economic Planning: Critical Studies on the Possibilities of Socialism. Clifton, N.J.: A. M. Kelly.

Hidalgo, César, Bailey Klinger, Albert-Laszlo Barabasi and Ricardo Hausmann (2007) “The Product Space Conditions the Development of Nations”, Science, 317(5837): 482487, 27 July 2007.

Hirschman, Albert (1958) The Strategy of Economic Development, New Haven, CT: Yale University Press.

Independent Evaluation Group (2008) Doing Business: An Independent Evaluation, World Bank Independent Evaluation Office, available at http://siteresources.worldbank.org/EXTDOIBUS/Resources/exec_summary.pdf

Kornai, János (1990) The Road to a Free Economy: Shifting from a Socialist System: The Example of Hungary. New York, NY, W. W. Norton.

Kornai, Janos (1992) The Socialist System: The Political Economy of Communism, Princeton Paperbacks.

Kornai, János (2006), By Force of Thought, Cambridge, Mass.: MIT Press.

Kornai, Janos and Tamás Lipták (1971) [1965] “Two-Level Planning” in Selected Readings in Economic Theory" edited by Keneth J. Arrow, pp.412-440., Cambridge, Mass., MIT Press.

Kremer, Michael (1993) "The O-Ring theory of economic development," Quarterly Journal of Economics 108 (1993):551-575.

Krueger, Anne O. (1974) "The Political Economy of the Rent-Seeking Society”, American Economic Review, Vol. 64 No. 3, Jun., 1974, 291-303.

Lindblom, Charles E. (1968) The Policy-Making Process, New Jersey: Prentice-Hall. North, Douglas (1990) Institutions, Institutional Change and Economic Performance, Cambridge University Press.

Olson, Mancur (1965) The Logic of Collective Action: Public Goods and the Theory of Groups, Harvard University Press.

Olson, Mancur (1982) The Rise and Decline of Nations: Economic Growth, Stagflation, and Social Rigidities, Yale University Press.

Pritchett, Lant (2008) "Reform is like a box of chocolates: An Interpretive Essay on Understanding the Pleasant and Unpleasant Surprises of Policy Reform”, mimeo Harvard University 
Rodriguez, Francisco (2007) "Cleaning up the kitchen sink: growth empirics when the world is not simple", mimeo Wesleyan University, available at

http://frrodriguez.web.wesleyan.edu/docs/working_papers/cleaning_up_the_kitchen_sink .pdf

Rodrik, Dani (2000) Institutions for high-quality growth: what they are and how to acquire them” Studies in Comparative International Development, Fall.

Rodrik, Dani (2007) One Economics, Many Recipes, Princeton University Press.

Rodrik, Dani and Arvind Subramanian (2004) "From "Hindu Growth" to Productivity Surge: The Mystery of the Indian Growth Transition”, IMF Working paper.

Romer, Paul (1993) "Implementing a National Technology Strategy with SelfOrganizing Industry Investment Boards”, Brookings Papers on Economic Activity. Microeconomics, Vol. 1993, No. 2 (1993), pp. 345-399

Schumpeter, J. A. (1934). The Theory of Economic Development: An Inquiry into Profits, Capital, Credit, Interest, and the Business Cycle. (1949 ed.). Cambridge, MA: Harvard University Press.

Stein, Ernesto, Mariano Tomassi, Koldo Echebarría, Eduardo Lora and Mark Payne (2006) The Politics of Policies, Economic and Social Progress Report, Washington: InterAmerican Development Bank.

Stigler, George J. (1971) “The Theory of Economic Regulation”, The Bell Journal of Economics and Management Science, Vol. 2, No. 1 (Spring, 1971), pp. 3-21.

Williamson, John (1990) Latin American Adjustment: How Much Has Happened? , Washington DC: Institute for International Economics.

Williamson, Oliver (1975) Markets and Hierarchies: Analysis and Antitrust Implications, The Free Press, New York.

Williamson, Oliver (1985) The Economic Institutions of Capitalism: Firms, Markets, Relational Contracting, The Free Press, New York. 